\title{
Periorbital emphysema following dental procedure: A case report and literature review
}

\section{Enfisema periorbitario secundario a procedimiento dental: reporte de un caso y revisión de la literature}

\author{
Mario Rodríguez-Calzadilla ${ }^{1 *}$, Mercedes García-Vázquez², María Contreras-Espuny ${ }^{1}$, \\ Alejandro Soto-Guerrero ${ }^{1}$, Alejo Honesto Rodríguez-Suárez ${ }^{1}$, Francisco Javier Benítez-del-Castillo-Sánchez ${ }^{1}$ \\ and Manuel García-Íñiguez ${ }^{1}$ \\ 1Ophthalmology Service, Jerez Hospital, Jerez de la Frontera, Cádiz; ${ }^{2}$ Ophthalmology Service, Virgen del Rocío Hospital, Seville. Spain
}

\begin{abstract}
Clinical case: The case concerns a 57-year-old woman who came to the Ophthalmology Emergency Service referred by her dentist after presenting a left periorbital swelling during a root canal treatment. A complete examination only revealed a soft, smooth periorbital tumefaction, crackling on palpation, with no associated inflammation. No radiological examinations were performed. Discussion: Subcutaneous emphysema has been described as a rare complication in the usual dental practice. Periorbital involvement is exceptional and usually has a good prognosis. In this paper, we describe a new case, reviewing the literature on the subject, analyzing the pathophysiology of the process and the changes in its epidemiology. Furthermore, recommendations for their management are established.
\end{abstract}

Key words: Subcutaneous emphysema. Periorbital emphysema. Orbital emphysema. Endodontics. Endodontics complication. Dentistry complication.

\section{Resumen}

Caso clínico: Mujer de 57 años acude a urgencias remitida por su odontóloga por haber presentado súbitamente un cuadro de tumefacción periorbitaria izquierda durante el transcurso de una endodoncia. Al examinar a la paciente apreciamos a dicho nivel una tumefacción a modo de rodete sobreelevado, sin inflamación asociada, blanda, tersa y crepitante a la palpación. El resto de la exploración es rigurosamente normal. No se realizaron pruebas de imagen. Discusión: El enfisema subcutáneo ha sido descrito como una complicación infrecuente en la práctica odontológica habitual. La forma de afectación periorbitaria es excepcional y no suele revestir gravedad. En este trabajo aprovechamos la descripción de un nuevo caso para revisar la literatura al respecto, repasando la fisiopatología del proceso y los cambios que intuimos en su epidemiología. Además, se establecen recomendaciones para su manejo.

Palabras clave: Enfisema subcutáneo. Enfisema periorbitario. Enfisema orbitario. Endodoncia. Complicación endodoncia. Complicación odontología. 


\section{Introduction}

Subcutaneous emphysema consists of the appearance of a cavity filled with air or another gas under the skin or mucosa after infiltration into the tissues through a pathological route. This gas outbreak can be induced naturally by trauma, cough, or Valsalva maneuver, or it can have an iatrogenic origin, mainly during various head-and-neck procedures or after anesthetic techniques ${ }^{1}$. Subcutaneous emphysema has been described as an infrequent complication of dental procedures performed in daily clinical practice. Specifically, the periorbital presentation of emphysema has been defined as an exceptional finding ${ }^{2}$. From the references published to date, there are only 13 cases describing periorbital involvement; ours is the $14^{\text {th }}$ literature reference.

\section{Clinical case}

A previously healthy 57 -year-old female was sent by her odontologist to the emergency department due to sudden left periorbital swelling during a root canal treatment. She handed us a report stating that the complication arose while using air pressure with a triple syringe on tooth number 27 (upper left second molar). The dentist then applied a temporary obturation and advised to consult the ophthalmologist on duty at the nearest hospital.

On visual examination, the left periorbital region showed a donut-shaped swelling, without associated inflammation (Fig. 1). Upon palpation, according to the classic sign, the mass was soft and smooth, with crepitation, so the diagnosis of subcutaneous emphysema was confirmed. There was no proptosis, pain, ocular motility alterations, visual deficit, diplopia, or any other data suggestive of orbital involvement, so we decided not to perform imaging tests. Visual acuity was 20/20 in both eyes, intraocular pressure was $16 / 17 \mathrm{mmHg}$, and both slit lamp and fundus examination were normal. Given the absence of data suggestive of a complication, we just prescribed oral antibiotics against the oropharyngeal flora (amoxicillin-clavulanic acid $875 / 125 \mathrm{mg} / 8 \mathrm{~h}$ ) as prophylaxis against possible orbital infections secondary to the vehiculization of said microorganisms from the oral cavity due to the airflow. We added a nonsteroidal anti-inflammatory drug (ibuprofen $600 \mathrm{mg} / 8 \mathrm{~h}$ ) to counteract local discomfort. After several hours, the emphysema began to resolve, and complete reabsorption was observed after 7 days (Fig. 2).

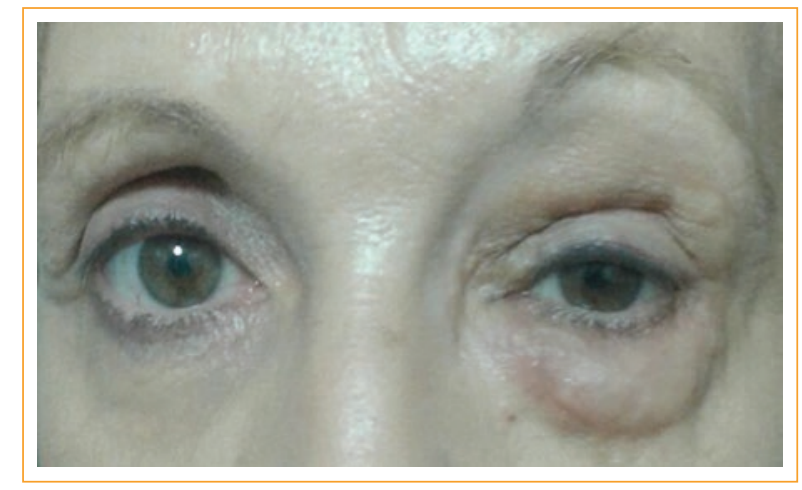

Figure 1. Appearance at the time of diagnosis.

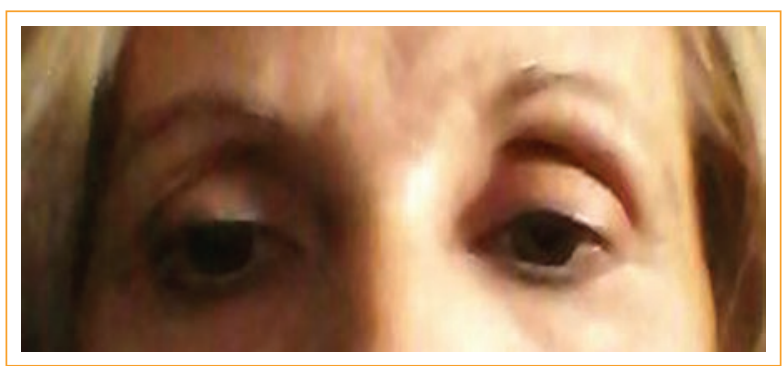

Figure 2. Resolved emphysema.

\section{Discussion}

Subcutaneous emphysema secondary to dental procedures is triggered by an increase of intraoral pressure. It was described at the beginning of the $20^{\text {th }}$ century by Turnbull and since then and for decades, the cases reported have been anecdotal, since they were associated exclusively with patient actions that may raise the pressure in the oral cavity ${ }^{1,2}$. With the introduction in daily dental practice of devices that use air pressure, it was expected that the incidence of subcutaneous emphysema would increase, given that they are able to artificially and autonomously produce considerable increases in intraoral pressure independent of patient's actions. Although there has been an increase in the incidence of this type of emphysema, it has remained a rare complication given its low relative frequency, and periorbital emphysema is more an anecdotal occurrence ${ }^{2}$.

In 2013, Mishra et al. published a new case with a retrospective review of the literature. The first article they found referred to a case of periorbital emphysema secondary to a dental procedure (Shoveton, 1957), and they just found another 5 publications on the subject, theirs being the sixth2,3.

In 2016, our team, in relation to the case report presented here, reviewed the literature and discovered a 
significant increase in the incidence of this entity. In just 3 years, there have been several references that add a total of 13 if we consider the six previous ones, and our case is number 14 of those existing to date ${ }^{4-9}$.

Periorbital subcutaneous emphysema seems to be an emerging complication in modern dental practice ${ }^{4-9}$. Despite this, its relative frequency is minimal and, given its benign nature, its clinical impact is negligible.

In this type of secondary subcutaneous emphysema, the air usually has as a pathological entry through the opening caused on dentin by the dental procedure. From that point, it enters into the pulp located in the root canals and moves until it encounters the alveolar processes on the maxilla (upper teeth) or on the mandible (lower teeth), where it opens a false rout to its fortuitous destiny. Nevertheless, this arbitrary route follows certain basic anatomical rules, such as that the superior teeth direct the air toward facial, orbital, pterygomaxillary, and sometimes cervical spaces, while the inferior ones lead to retropharyngeal, mediastinal, pericardial, and thoracic spaces ${ }^{2}$. In the same way and as is logical, the air tends to be directed toward spaces homolateral to the treated tooth. The most frequently involved teeth, due to their size and anatomy, are the first, second, and third molars ${ }^{10}$. A clear example of these rules of anatomical distribution is our patient, who suffered a left orbital emphysema while performing a root canal procedure on the pulp of tooth number 27 (upper second left molar). In addition, it is logical to deduce that subcutaneous emphysema derived from procedures on the upper teeth will usually be less serious than those due to techniques performed on the inferior teeth, where propagation routes can compromise vital regions.

\section{Conclusions}

Given the excellent prognosis and the natural tendency of periorbital emphysema to resolve without intervention, the therapeutic measures discussed are more than enough in the absence of data suggestive of complications. According to our internal protocol, it is not necessary to perform imaging tests in the absence of another clinical signs. Computed tomography has been practiced routinely by some authors; we estimate that in the presence of few symptoms such as in the case presented and as long as there are no warning signs, imaging tests may not be necessary for the management of this condition ${ }^{10}$.

This recommendation acquires special relevance in the current epidemiological context, given the increasing incidence of this entity observed in recent years ${ }^{4-9}$. To avoid unnecessary irradiation and optimize resources, imaging tests should be reserved for selected cases that have symptoms suggestive of complications. It can also be assumed that in the future, we will witness an even greater increase in the incidence of this disorder, parallel to the technological advance in equipment; these will acquire progressively more power and a greater capacity to induce emphysema. On the other hand, the human body - the other piece of this chess of pressures - will remain the same, at least for now...and this will keep it vulnerable to these "stray bullets" of air.

\section{Funding}

There is no source of funding.

\section{Conflicts of interest}

The authors declare no conflicts of interest.

\section{Ethical disclosures}

Protection of human and animal subjects. The authors declare that no experiments were performed on humans or animals for this study.

Confidentiality of data. The authors declare that they have followed the protocols of their work center on the publication of patient data.

Right to privacy and informed consent. The authors have obtained the written informed consent of the patients or subjects mentioned in the article. The corresponding author is in possession of this document.

\section{References}

1. Uyanık LO, Aydın M, Buhara O, et al. Periorbital emphysema during dental treatment: A case report. Oral Surg Oral Med Oral Pathol Oral Radiol Endod. 2011;112:94-6.

2. Mishra L, Patnaik S, Patro S, et al. latrogenic subcutaneous emphysema of endodontic origin - case report with literature review. J Clin Diagn Res. 2014;8:279-81.

3. Shoveton DS. Surgical emphysema complications of dental operations. Brt Dental J. 1957:102:25.

4. Parkar A, Medhurst C, Irbash M, et al. Periorbital oedema and surgical emphysema, an unusual complication of a dental procedure: A case report. Cases J. 2009;2:8108.

5. Haitz KA, Patel AJ, Baughman RD. Periorbital subcutaneous emphysema mistaken for unilateral angioedema during dental crown preparation. JAMA Dermatol. 2014;150:907-9.

6. An GK, Zats B, Kunin M. Orbital, mediastinal, and cervicofacial subcutaneous emphysema after endodontic retreatment of a mandibular premolar: A case report. J Endod. 2014;40:880-3.

7. Fleischman D, Davis RM, Lee LB. Subcutaneous and periorbital emphysema following dental procedure. Ophthal Plast Reconstr Surg. 2014;30:43-5.

8. Al-Qudah A, Amin F, Hassona Y. Periorbital emphysema during endodontic retreatment of an upper central incisor: A case report. Br Dent J. 2013;215:459-61.

9. Khandelwal V, Agrawal P, Agrawal D, Nayak PA. Subcutaneous emphysema of periorbital region after stainless steel crown preparation in a young child. BMJ Case Rep. 2013, http://dx.doi.org/10.1136/bcr-2013-009952

10. Hsu HL, Chang CC, Liu KL. Subcutaneous emphysema after dental procedure. QJM. 2011;104:545 